\title{
EFFECTS OF DIFFERENT FERTILIZER TREATMENTS ON GRAIN YIELD AND YIELD COMPONENTS OF SPRING WHEAT
}

\author{
Marzena Mikos-Szymańska ${ }^{1}$, Mieczysław Borowik' ${ }^{1}$, Marta Wyzińska² ${ }^{2}$ Piotr Rusek ${ }^{1}$ \\ ${ }^{1}$ New Chemical Syntheses Institute, Poland \\ ${ }^{2}$ Institute of Soil Science and Plant Cultivation - State Research Institute, Poland \\ marzena.mikos-szymanska@ins.pulawy.pl
}

\begin{abstract}
The present research was carried out to investigate the effects of different fertilizer treatments on grain yield and yield components of spring wheat (Triticum aestivum L.) 'Harenda' cultivar. The five treatments were as follows: control (standard NPK fertilization), standard NPK fertilization plus liquid NPK (10-11-11) fertilizer, standard NPK fertilization plus liquid NPK (10-11-11) fertilizer with microelements, standard NPK fertilization plus calcium micronized suspension fertilizer, and standard NPK fertilization plus $\mathrm{Cu}, \mathrm{Mn}, \mathrm{Zn}, \mathrm{Ca}$ micronized suspension fertilizers. The field trials were conducted in 2017 at the Experimental Site of Institute of Soil Science and Plant Cultivation - State Research Institute in Puławy, Poland. Applications of calcium micronized suspension foliar fertilizer and a mixture of $\mathrm{Cu}, \mathrm{Mn}, \mathrm{Zn}$, Ca micronized suspension fertilizers significantly increased grain yield of spring wheat, respectively by $44.5 \%$ and $38.6 \%$ in comparison with control (standard NPK fertilization). These fertilizer treatments also enhanced yield components of spring wheat. Moreover, micronized suspension fertilizers ( $\mathrm{Ca}$ and the mixture of $\mathrm{Cu}, \mathrm{Mn}, \mathrm{Zn}, \mathrm{Ca}$ ) had a significant effect on ear number and thousand grain weight of spring wheat compared to control and NPK fertilizers. Liquid NPK and micronutrient-enriched NPK fertilizers had a significant effect on thousand grain weight compared to control.
\end{abstract}

Key words: liquid fertilizer, micronized suspension, microelement, fertilization.

\section{Introduction}

Spring wheat (Triticum aestivum L.) is an important grain crop in Poland and in the world. Because of the increase in the rate of population growth and the decrease of areas of arable land, improving the grain yield is the way to meet food demand. Grain yield of cereals is the product of the following components: the number of spikes per unit area, the number of kernels per spike and thousand kernel weight (Bulman $\&$ Hunt, 1988). It can be increased due to the use of improved cultivars and nutrient management. Optimal fertilizer management is necessary to maintain sustainable yields, improve nutrient use efficiency of fertilizers, and save fertilizer resources (Chuan et al., 2016). The macro- and micronutrients play an important role in the crop nutrition and thus they are important for achieving higher yields, better growth and development of plants (Imran \& Gurmani, 2011). Nitrogen $(\mathrm{N})$, phosphorus $(\mathrm{P})$, and potassium $(\mathrm{K})$ are primary nutrients in crop nutrition. $\mathrm{N}$ is a primary constituent of proteins, enzymes, chlorophyll, and metabolic processes involved in the synthesis and transfer of energy (Raun \& Johnson, 1999). P is a component of energy compounds (e.g., ATP and ADP) and thus it is involved in biochemical pathways. Orthophosphates play a role in plant metabolic processes such as photosynthesis and respiration (Plaxon \& Tran, 2011). Potassium is vital for growth as an enzyme activator that promotes metabolism. K provides abiotic stress tolerance (e.g. under drought stress), regulate stomatal opening and helps plants adapt to water deficit (Hasanuzzaman et al., 2018). Calcium $(\mathrm{Ca})$ is a regulator of physiological and biochemical processes in plants, especially in response to abiotic stresses (Bowler \& Fluhr, 2000). This element is known as a second messenger and can delay or promote leaf senescence (Bowler \& Chua, 1994), which is a terminal stage of leaf development (Thakur, Sharma, \& Kishore, 2016). Ca is also believed to have an influence on the development of heat shock proteins that help the plant tolerate the stress of prolonged heat (Goswami et al., 2014). Foliar calcium applications enhanced wheat yield and its components, increased transpiration rates, photosynthesis rate, stomatal conductance and chlorophyll content in spring wheat (Dolatabadian et al., 2013). Micronutrients (i.e., Fe, $\mathrm{Cu}, \mathrm{Zn}, \mathrm{B}, \mathrm{Mn}$, and $\mathrm{Mo}$ ) are required for growth of plants (Welch et al., 1991). According to Stępień \& Wojtkowiak (2016), micronutrients such as $\mathrm{Cu}, \mathrm{Mn}$, and $\mathrm{Zn}$ are mostly needed by plants. Many studies have showed that small quantities of foliar-applied micronutrients (solitary or in association with others) significantly increase yield, its components and enhance growth and quality of wheat grain (Ziaeian \& Malakouti, 2001; Asad \& Rafique, 2002; Ali et al., 2009; Ali, 2012; Raza et al., 2014; Gomaa et al., 2015; Rawashdeh \& Sala, 2015). Zinc ( $\mathrm{Zn})$ is responsible for the formation of growth hormones (auxin), seed and grain formation, plant height, protein syntheses, transformation and consumption of carbohydrates. $\mathrm{Zn}$ is known to have an important role as metal component of enzymes or as a functional, structural or regulatory cofactor of a wide number of enzymes (Hotz \& Braun, 2004; Esfandiari et al., 2016). Copper $\mathrm{Cu}$ is an enzyme activator, plays an important role in the metabolism of $\mathrm{N}$ compounds and indirect 
role in chlorophyll production, and increases sugar contents. Micronutrients such as $\mathrm{Mn}$ and $\mathrm{Zn}$ have an effect on protein biosynthesis by adjusting the activity of peptidases and controlling protein metabolism (Ronen, 2007; Hänsch \& Mendel, 2009). Iron (Fe) promotes formation of chlorophyll as well as enzyme mechanism which operates the respiratory systems of cells and is involved in reactions of cell division and growth (Ronen, 2007).

There are known several types of fertilizer applications. One of the methods is broadcasting of fertilizers over the soil surface (Finck, 1982). Another method is a foliar fertilization, also known as foliar feeding. It is a technique of feeding plants by applying liquid fertilizers directly on the leaves or the stem (Nasiri et al., 2010). Fertilizers used for foliar applications are in solution or suspension. Because of the fast absorption of nutrients through the leaf cuticle or stomata, the deficiencies of macroand microelements can be quickly corrected after being diagnosed by observation or foliar analysis. Low application rates and uniform distribution of nutrients are the main advantages of this type of application (Finck, 1982). Despite the fact that foliar fertilization is supplementary and cannot replace the basal fertilization, it is very effective. Foliar feeding should be done during periods of low temperature and relatively high humidity. The best results of feeding can be obtained during cloudy weather, in the early morning or in the evening. The application of foliar liquid fertilizers in concentrations above the recommended doses can cause leaf burning and necrosis.

The major types of fluid fertilizers are clear liquids and suspension fertilizers. Clear liquids are completely water-soluble while suspensions are partially dissolved in water, and the nutrients are suspended in the saturated solution. Suspension fertilizers are characterized by higher concentrations of nutrients than solutions of liquid clear fertilizers. Materials of low solubility are used for production of suspensions. The stability of the suspension is a major problem in this form of fertilizers. Gelling type clays (e.g., bentonite, aluminosilicates) are added in order to prevent the settling of solids and to keep the suspension stable. Nevertheless, prolonged storage of several months is not recommended for these type of fertilizers (Hagin \& Tucker, 1982). One critical, although hard-to-predict, determinant of a successful foliar fertilization is the amount of ions taken up by the leaf via cuticular and stomatal pathways (Fernandez \& Brown, 2013; Kaiser, 2014). In recent years, studies have shown that aqueous stomatal uptake under certain conditions is possible (Eichert \& Burkhardt, 2001; Burkhard \& Hunsche, 2013; Kaiser, 2014). Recently, new products for foliar applications containing suspended mineral microparticles have emerged on the market (Kaiser, 2014). The latest direction of research on the intentional formation of fertilizer composition to obtain better quality characteristics of crops, is a search for a very specific composition of foliar fertilizers, which would act stimulatingly in the desired direction of changes in yield characteristics (Tripolskaja et al., 2017).

The aim of the study was to compare the effect of different fertilizer treatments (standard NPK fertilization (control), standard NPK fertilization plus NPK foliar fertilizer, standard NPK fertilization plus NPK micronutrient-enriched foliar fertilizer, standard NPK fertilization plus calcium micronized suspension foliar fertilizer, and standard NPK fertilization plus the mixture of $\mathrm{Cu}, \mathrm{Mn}, \mathrm{Zn}$, Ca micronized suspension foliar fertilizers) on grain yield and yield components of spring wheat (Triticum aestivum L.). Liquid NPK micronutrient-enriched fertilizer was applied once at the tillering phase of wheat, and other liquid fertilizers were applied at the tillering and stem elongation phases. These fertilizers were tested for the first time in field experiments.

\section{Materials and Methods}

The new innovative formulas of liquid fertilizers were used: liquid NPK fertilizer, liquid NPK micronutrient-enriched fertilizer, and $\mathrm{Ca}, \mathrm{Cu}, \mathrm{Mn}$, $\mathrm{Zn}$ suspension fertilizers obtained at the Fertilizer Research Centre of New Chemical Syntheses Institute, Poland.

A field experiment was carried out in 2017 at the Institute of Soil Science and Plant Cultivation (IUNGPIB) Experimental Site in Puławy, Poland. A spring wheat cultivar 'Harenda' was used in the experiment. A trial was set up in a randomized complete block design with five different fertilizer treatments with three replications. Treatments were as follows:

1. $\mathrm{T}_{1}$ - Control - standard NPK fertilization: $50 \mathrm{~kg}$ $\mathrm{N} \cdot \mathrm{ha}^{-1}$ as $34 \%$ ammonium nitrate (AN), $80 \mathrm{~kg} \mathrm{P}_{2} \mathrm{O}_{5} \cdot \mathrm{ha}^{-1}$ as granular triple superphosphate, $100 \mathrm{~kg} \mathrm{~K} \mathrm{~K}_{2} \cdot \mathrm{ha}^{-1}$ as potassium salt before sowing and $40 \mathrm{~kg} \mathrm{~N} \cdot \mathrm{ha}^{-1}$ as $34 \%$ ammonium nitrate at the stem elongation phase (BBCH 32);

2. $\mathrm{T}_{2}-$ standard NPK fertilization plus liquid NPK (10-11-11) fertilizer at doses of $10 \mathrm{~L} \cdot \mathrm{ha}^{-1}$ at the tillering (BBCH 20) and $5 \mathrm{~L} \cdot \mathrm{ha}^{-1}$ at the stem elongation phase (BBCH 32) (foliar application);

3. $\mathrm{T}_{3}-$ standard NPK fertilization plus liquid NPK (10-11-11) fertilizer with microelements $(0.01 \% \mathrm{~B}$, $0.03 \%$ Fe- EDTA, $0.01 \%$ Mn-EDTA, $0.001 \%$ Mo, $0.004 \% \mathrm{Zn}$-EDTA, $0.004 \% \mathrm{Cu}-\mathrm{EDTA})$ at one dose of $5 \mathrm{~L} \cdot \mathrm{ha}^{-1}$ at the tillering phase $(\mathrm{BBCH} 20)$ (foliar application);

4. $\mathrm{T}_{4}-$ standard NPK fertilization plus calcium micronized suspension fertilizer $(19.5 \% \mathrm{Ca})$ at two 
Soil properties (layer 0-30 cm) at the IUNG-PIB experimental site

Table 1

\begin{tabular}{|c|c|c|c|}
\hline Parameter & Method & Unit & Value \\
\hline $\mathrm{pH}(\mathrm{KCl})$ & potentiometrically & - & 6.6 \\
\hline Nmin, DM & gravimetric method & $\%$ & 85.9 \\
\hline $\mathrm{N}-\mathrm{NO}_{3}$ & CFA with spectrophotometric detection & $\mathrm{mg} \cdot \mathrm{kg}^{-1}$ & 5.0 \\
\hline $\mathrm{N}-\mathrm{NH}_{4}$ & CFA with spectrophotometric detection & $\mathrm{mg} \cdot \mathrm{kg}^{-1}$ & 2.4 \\
\hline available phosphorus $\left(\mathrm{P}_{2} \mathrm{O}_{5}\right)$ & spectrophotometric method & $\mathrm{mg} \cdot 100 \mathrm{~g}^{-1}$ & 26.9 \\
\hline available potassium $\left(\mathrm{K}_{2} \mathrm{O}\right)$ & FAES & $\mathrm{mg} \cdot 100 \mathrm{~g}^{-1}$ & 18.3 \\
\hline available Mg & FAAS & $\mathrm{mg} \cdot 100 \mathrm{~g}^{-1}$ & 7.4 \\
\hline $\mathrm{Ca}$ & FAAS & $\mathrm{mg} \cdot \mathrm{kg}^{-1}$ & 921 \\
\hline Corg & titration method & $\%$ & 0.59 \\
\hline organic matter & by calculation Corg x 1.724 & $\%$ & 1.02 \\
\hline
\end{tabular}

doses of $5 \mathrm{~kg} \mathrm{Ca} \mathrm{ha}^{-1}$ (26 kg of Ca suspension per ha, respectively) at the tillering $(\mathrm{BBCH} 20)$ and at the stem elongation phase (BBCH 32) (foliar application);

5. $\mathrm{T}_{5}$ - standard NPK fertilization plus $\mathrm{Cu}, \mathrm{Mn}$, $\mathrm{Zn}, \mathrm{Ca}$ micronized suspension fertilizers $(33 \% \mathrm{Cu}$, $23 \% \mathrm{Mn}, 51 \% \mathrm{Zn}, 19.5 \% \mathrm{Ca})$ at two doses of $100 \mathrm{~g}$ $\mathrm{Cu} \cdot \mathrm{ha}^{-1}, 300 \mathrm{~g} \mathrm{Mn} \cdot \mathrm{ha}^{-1}, 400 \mathrm{~g} \mathrm{Zn} \cdot \mathrm{ha}^{-1}$, and $5 \mathrm{~kg} \mathrm{Ca} \mathrm{ha}{ }^{-1}$ (a mixture of $0.303 \mathrm{~kg}$ of Cu suspension $+1.305 \mathrm{~kg}$ of Mn suspension $+0.785 \mathrm{~kg}$ of $\mathrm{Zn}$ suspension $+26 \mathrm{~kg}$ of $\mathrm{Ca}$ suspension per ha, respectively) at the tillering $(\mathrm{BBCH} 20)$ and at the stem elongation phase $(\mathrm{BBCH}$ 32) (foliar application).

Foliar solutions were sprayed with a hand held spray bottle at the rate of $400 \mathrm{~L} \cdot \mathrm{ha}^{-1}$ on plant foliage. Spring wheat was sown in an amount ensuring a density of 450 plants per $\mathrm{m}^{2}$. The area of each plot was
$1 \mathrm{~m}^{2}$. The soil chemical characteristics at experimental site can be seen in Table 1. Data on the yield and yield components were recorded. Plants with roots were collected from each plot $\left(1 \mathrm{~m}^{2}\right)$ by hand, then labelled and plant number per $1 \mathrm{~m}^{2}$ was counted. After harvest, productive tillers from each plot were cut using scissors and then counted. Grain yield per plant, grain yield per ear, the number of kernels per plant, and the number of kernels per ear were mathematically calculated using Excel formulas. Exactly 100 kernels from each plot were counted and weighted in three replications and the results were multiplied by 10 in order to calculate thousand grain weight.

The spring wheat vegetation period in 2017 was characterized by much higher average monthly temperatures compared to long term averages (Figure

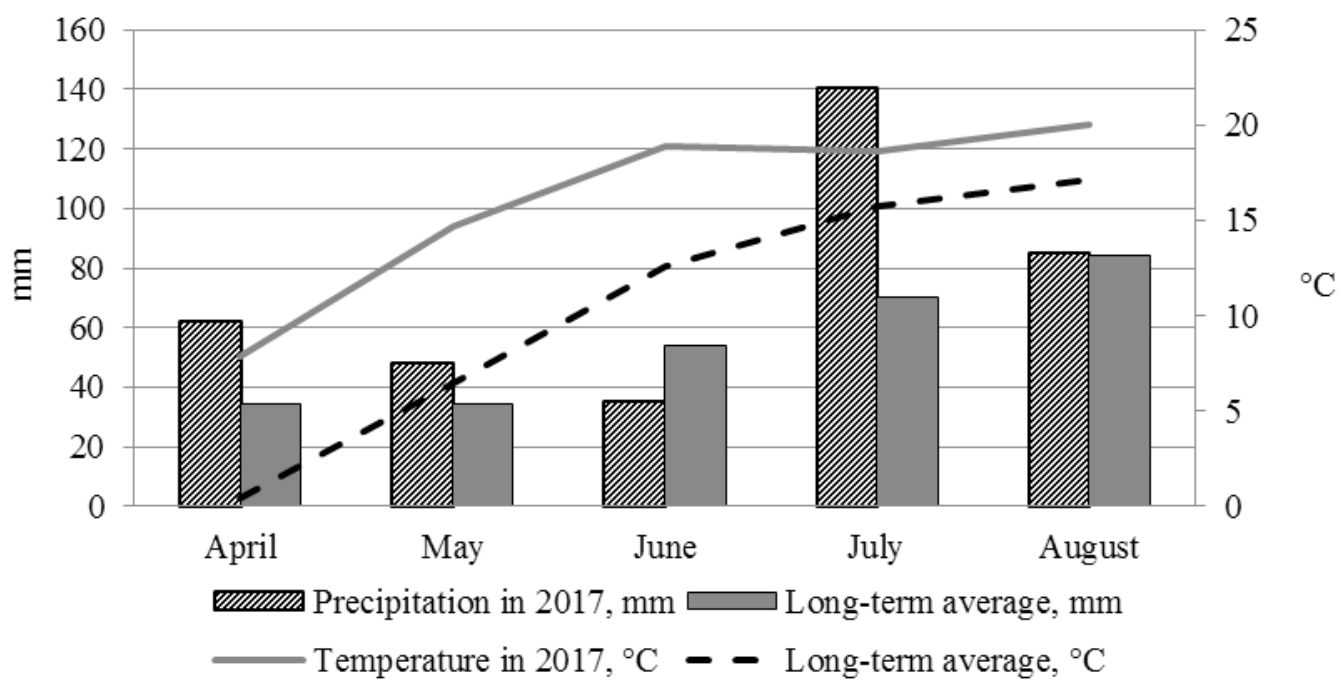

Figure 1. Weather conditions in 2017 and the long term average data (1971 - 2007). 
1). In the growing season, the average temperature was $16^{\circ} \mathrm{C}$, and the sum of precipitation was $371 \mathrm{~mm}$. In June, precipitations were lower $(35.4 \mathrm{~mm})$ than the long-term average precipitation data $(54.2 \mathrm{~mm})$. In contrast, the sum of precipitation in July $(140.5 \mathrm{~mm})$ was two-fold higher than the long term average value (70 mm).

The productive tillering coefficient (PTC) was calculated by the following formula:

$$
\text { PTC }=\frac{\text { mumber of produvtive tillers } \cdot \mathrm{m}^{-2}}{\text { mumber of overwintered plants } \cdot \mathrm{m}^{-2}}
$$

Statistical evaluation was carried out using the Statgraphics Centurion v. XVI. Analysis of variance was performed with Tukey's confidence interval at a significance level of $\alpha=0.05$.

\section{Results and Discussion}

Analysis of the results showed a significant beneficial effect of micronized suspension and liquid clear fertilizers on grain yield of spring wheat. The highest grain yield was observed under applications of $\mathrm{Ca}$ and the mixture of $\mathrm{Cu}, \mathrm{Mn}, \mathrm{Zn}, \mathrm{Ca}$ micronized suspension fertilizers (831.6 and $751.9 \mathrm{~g} \cdot \mathrm{m}^{-2}$, respectively) increasing respectively by $369.9 \mathrm{~g} \cdot \mathrm{m}^{-2}$ (44.5\%) and by $290.2 \mathrm{~g} \cdot \mathrm{m}^{-2}(38.6 \%)$ with respect to control. Between $\mathrm{T}_{1}, \mathrm{~T}_{2}$, and $\mathrm{T}_{3}$ treatments there were no statistically significant differences $(p \geq 0.05)$. But, there was only a tendency of higher grain yield after the application of NPK liquid and NPK micronutrientenriched liquid fertilizer compared to control (by 15.7 and $11.7 \%$, respectively) (Fig. 2). This may be due to a better crop nutrition through foliar application of suspension and clear liquid fertilizers, and also due to important roles of macro- $(\mathrm{N}, \mathrm{P}, \mathrm{K}, \mathrm{Ca})$ and micronutrients $(\mathrm{Cu}, \mathrm{Mn}, \mathrm{Zn}, \mathrm{B}, \mathrm{Fe}, \mathrm{Mn}, \mathrm{Mo})$ in plant growth and development which may result in improved crop growth and increased production. Jarecki, Buczek \& Bobrecka-Jamro (2017) reported that three foliar fertilizations increased grain yield in comparison with control. Ali (2012) reported that foliar application of $\mathrm{Fe}$ enhanced grain yield as compared to control. The highest grain yield per plant was observed under the application of the mixture of $\mathrm{Cu}, \mathrm{Mn}, \mathrm{Zn}, \mathrm{Ca}$ micronized suspension fertilizers $\left(\mathrm{T}_{5}\right)$, followed by $\mathrm{T}_{4}, \mathrm{~T}_{3}$, and $\mathrm{T}_{2}$ treatments. Between $\mathrm{T}_{1}, \mathrm{~T}_{2}, \mathrm{~T}_{3}$, and $\mathrm{T}_{4}$ treatments, there were no statistically significant differences in grain yield per plant $(\mathrm{p} \geq 0.05)$. The highest grain yield per ear was observed under $\mathrm{Ca}$ micronized suspension fertilizer treatment $\left(\mathrm{T}_{4}\right)$, followed by $\mathrm{T}_{5}, \mathrm{~T}_{3}$, and $\mathrm{T}_{2}$ treatments.

Leszczyńska et al. (2007) reported that spring wheat cultivars require sowing of approximately 450 grains per $\mathrm{m}^{2}$, because of their poor tillering. According to our study, the fertilizer treatments did not significantly affect the plant number of spring wheat per $\mathrm{m}^{2}(\mathrm{p} \geq 0.05)$. The plant number ranged from 251 to 313 plants per $\mathrm{m}^{2}$ (Table 2) whereas the sowing density was 450 grains per $\mathrm{m}^{2}$.

Analysis of the results showed a significant beneficial effect of micronized suspension and NPK liquid fertilizers on the ear number of spring wheat. The highest ear number was stated under $T_{5}$ and $\mathrm{T}_{4}$ fertilizer treatments (micronized suspension fertilizers) as compared to control. Between the control (standard NPK fertilization), NPK fertilizer $\left(\mathrm{T}_{2}\right)$ and NPK micronutrient-enriched fertilizer treatments $\left(\mathrm{T}_{3}\right)$, there were no statistically significant differences in the ear number of spring wheat ( $\mathrm{p} \geq 0.05)$ (Table 2). Bobrecka-Jamro, Jarecka \& Jarecki (2015) confirmed that a higher NPK dose significantly increases the ear number per $1 \mathrm{~m}^{2}$. Seadh et al. (2009)

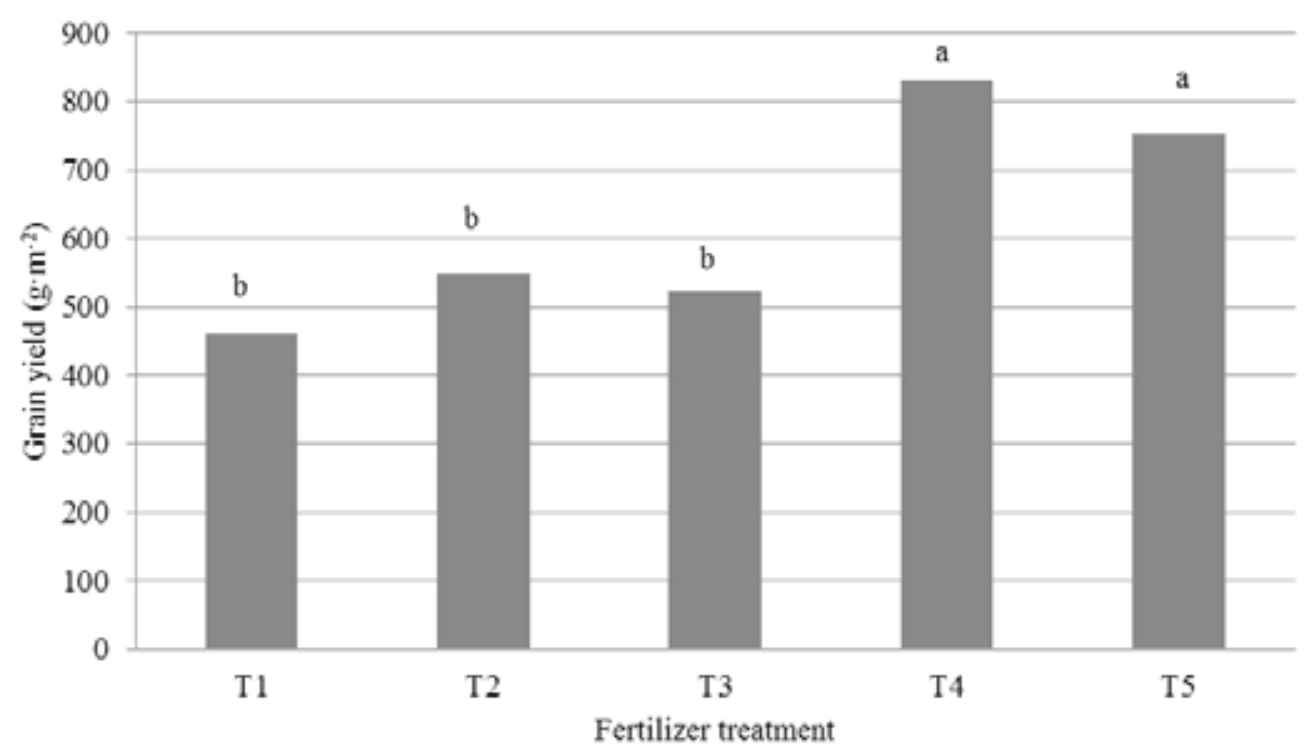

Figure 2. Grain yield $\left(\mathrm{g} \cdot \mathrm{m}^{-2}\right)$ of spring wheat in 2017 . 
Yield components and a productive tillering coefficient of spring wheat

Table 2

\begin{tabular}{|l|c|c|c|c|c|c|c|c|}
\hline \multicolumn{1}{|c|}{ Treatment } & PN & EN & $\begin{array}{c}\text { TGW } \\
(\mathrm{g})\end{array}$ & $\begin{array}{c}\text { GYP } \\
\left(\mathrm{g} \cdot \text { plant }^{-1}\right)\end{array}$ & $\begin{array}{c}\text { GYE } \\
\left(\mathrm{g} \cdot \text { ear }^{-1}\right)\end{array}$ & NKP & NKE & PTC \\
\hline T1 & 251 & $442 \mathrm{~b}$ & $38.2 \mathrm{c}$ & $1.87 \mathrm{bc}$ & $1.04 \mathrm{~b}$ & 49 & 27 & 1.79 \\
\hline T2 & 312 & $473 \mathrm{ab}$ & $41.5 \mathrm{~b}$ & $1.76 \mathrm{bc}$ & $1.16 \mathrm{ab}$ & 42 & 28 & 1.52 \\
\hline T3 & 262 & $453 \mathrm{~b}$ & $42.0 \mathrm{~b}$ & $2.01 \mathrm{ab}$ & $1.17 \mathrm{ab}$ & 48 & 28 & 1.73 \\
\hline T4 & 313 & $605 \mathrm{a}$ & $45.7 \mathrm{a}$ & $2.67 \mathrm{ab}$ & $1.37 \mathrm{a}$ & 58 & 30 & 1.94 \\
\hline T5 & 310 & $611 \mathrm{a}$ & $46.2 \mathrm{a}$ & $2.49 \mathrm{a}$ & $1.23 \mathrm{ab}$ & 55 & 27 & 2.01 \\
\hline
\end{tabular}

Notes: PN - plant number per $\mathrm{m}^{2}, \mathrm{EN}$ - ear number per $\mathrm{m}^{2}, \mathrm{TGW}$ - thousand grain weight, GYP - grain yield per plant, GYE - grain yield per ear, NKP - number of kernels per plant, NKE - number of kernels per ear, PTC - productive tillering coefficient. For each variable, means followed by the same letter are not significantly different at $\mathrm{p} \geq 0.05$ (Tukey HSD test).

reported that the application of a high nitrogen dose and a multi component foliar fertilizer has the most favourable effect on the number of ears per $1 \mathrm{~m}^{2}$. The study by Tahir et al. (2009) did not indicate the effect of foliar application of boron on the ear density. Arif et al. (2006), in turn, after the application of three-time foliar spraying, obtained a significant increase in the number of ears per $1 \mathrm{~m}^{2}$. Jarecki, Buczek \& BobreckaJamro (2017) reported that the use of higher NPK dose resulted in an increase in the number of ears of spring wheat per area unit in comparison with the lower dose.

The fertilizer treatments significantly affected thousand grain weight (TGW) (Table 2). The highest TGW was observed under micronized suspension fertilizer treatments $\left(\mathrm{T}_{4}, \mathrm{~T}_{5}\right)$, followed by NPK liquid fertilizer $\left(\mathrm{T}_{2}\right)$ and NPK with microelement liquid fertilizer $\left(\mathrm{T}_{3}\right)$ applications, and the lowest TGW was observed under standard NPK fertilization $\left(\mathrm{T}_{1}\right)$. Arif et al. (2006), Rawashdeh \& Sala (2016) and Jarecki, Buczek, \& Bobrecka-Jamro (2017) confirmed that foliar fertilization increases TGW in wheat, but on the condition of performing several sprayings during the growing season. Nadim et al. (2013) did not indicate the effect of microelements applied to soil or on leaves on TGW.

The fertilizer treatments had no significant effect on the number of kernels per plant ( $\mathrm{p} \geq 0.05$ ) (Table 2). The number of kernels per plant increased linearly with increased $\mathrm{N}$ availability (Oscarson, 2000).

Number of kernels per ear is one of the most important yield determinants. The fertilizer treatments had no significant effect on the number of kernels per ear $(p \geq 0.05)$ (Tab. 2). On the contrary, Arif et al. (2006) and Zain et al. (2015) reported that foliar application of nutrients had a significant effect on the number of kernels per ear. Esfandiari et al. (2016) reported that the foliar zinc application at the stage of grain development significantly increased grain yield by increasing the number of kernels per ear.

The fertilizer treatments had no significant effect on the productive tillering coefficient $(p \geq 0.05)$ (Table 2). But the tendency of having the highest productive tillering coefficients was observed only under $\mathrm{T}_{4}$ and $\mathrm{T}_{5}$ treatments (1.94 and 2.01, respectively).

\section{Conclusions}

The present research revealed that different fertilizer treatments had a significant effect on the grain yield and some of the yield components of spring wheat. The use of micronized suspension foliar fertilizers (T4 and T5) significantly enhanced grain yield and yield components of spring wheat as compared to control. Liquid NPK and micronutrientenriched NPK fertilizers (T2 and T3, respectively) had a significant effect on thousand grain weight as compared to control (T1). To confirm the results of the study, the field trials are being continued in 2018 .

\section{Acknowledgements}

The work is partially co-funded by the National Centre for Research and Development, a grant no. BIOENERGY/CtoCfarming/02/2016, entitled "Cradle to cattle farming (CtoC farming)", ERANET Bioenergy 8th Joint Call "Innovative Bioenergy Concepts".

\section{References}

1. Ali, E.A. (2012). Effect of Iron Nutrient Care Sprayed on Foliage at Different Physiological Growth Stages on Yield and Quality of Some Durum Wheat (Triticum durum L.) varieties in Sandy Soil. Asian Journal of Crop Science. 4 (4), 139-149. 
2. Ali, S., Shah, A., Arif, M., Miraj, G., Ali, I., Sajjad, M., Farhatullah, Khan, M.Y., \& Khan, N.M. (2009). Enhancement of wheat grain yield and yield components through foliar application of Zinc and Boron. Sarhad Journal of Agriculture. 25(1), 15-19.

3. Arif, M., Chohan, A.M., Ali, S., Gul, R., \& Khan, S. (2006). Response of wheat to foliar application of nutrients. Journal Agricultural and Biological Science. 1 (4), 30-34.

4. Asad, A., \& Rafique, R. (2002). Identification of micronutrient deficiency of wheat in the Peshawar valley, Pakistan. Communications in Soil Science and Plant Analysis. 33(3-4), 349-364.

5. Bulman, P., \& Hunt, L.A. (1988). Relationship among tillering, spike number and grain yield in winter wheat (Triticum aestivum L.) in Ontario. Canadian Journal of Plant Science. 68, 583-596.

6. Bobrecka-Jamro, D., Jarecka, A., \& Jarecki, W. (2015) Response of some spring wheat cultivars to diverse mineral NPK fertilization. Acta Scientiarum Polonorum Agricultura. 14 (2), 3-13.

7. Bowler, C., \& Fluhr, R. (2000). The role of calcium and activated oxygens as signals for controlling crosstolerance. Trends in Plant Science. 5, 241-246. DOI: 10.1016/S1360-1385(00)01628-9.

8. Bowler, C., \& Chua, N.H. (1994). Emergent themes of plant signal transduction. The Plant Cell. 6, 15281541 .

9. Burkhardt, J., \& Hunsche, M. (2013). Breath figures on leaf surfaces - formation and effects of microscopic leaf wetness. Frontiers in Plant Science. 4, 422-431.

10. Chuan, L., He, P., Zhao, T., Zheng, H., \& Xu, X. (2016). Agronomic characteristics related to grain yield and nutrient use efficiency for wheat production in China. PLoS ONE. 11(9):e0162802. DOI: 10.1371/ journal.pone.0162802.

11. Dolatabadian, A., Sanavy, S.A.M.M., Gholamhoseini, M., Joghan, A.K., Majdi, M., \& Kashkooli, A.B. (2013). The role of calcium in improving photosynthesis and related physiological and biochemical attributes of spring wheat subjected to simulated acid rain. Physiology and Molecular Biology of Plants. 19(2), 189-198. DOI: 10.1007/s12298-013-0165-7.

12. Eichert, T., \& Burkhardt, J. (2001). Quantification of stomatal uptake of ionic solutes using a new model system. Journal of Experimental Botany. 52, 771-781.

13. Esfandiari, E., Abdoli, M., Mousavi, S-B., \& Sadeghzadeh, B. (2016). Impact of foliar zinc application on agronomic traits and grain quality parameters of wheat grown in zinc deficient soil. Indian Journal of Plant Physiology. 21, 263-270. DOI: 10.1007/s40502-016-0225-4.

14. Fernandez, V., \& Brown, P.H. (2013). From plant surface to plant metabolism: the uncertain fate of foliarapplied nutrients. Frontiers in Plant Science. 4, 289-293.

15. Finck, A. (1982). Fertilizers and Fertilization. Verlag Chimie GmbH, Weinheim, Germany. The International Potash Institute, Application of Fertilizers. Retrieved February 23, 2018, from: https:/www.ipipotash.org/ udocs/Chap-5_Application_of_fertilizers.pdf.

16. Gomaa, M.A., Radwan, F.I., Kandil, E.E., \& El-Zweek, S.M.A. (2015). Effect of some macro and micronutrients application methods on productivity and quality of wheat (Triticum aestivum L.). Middle East Journal of Agriculture Research. 4(1), 1-11.

17. Goswami, S., Kumar, R.R., Sharma, S.K., Kala, Y.K., Singh, K., Gupta, R., Dhavan, G., Rai, G.K., Singh, G.P., Pathak, H., \& Rai, R.D. (2014). Calcium triggers protein kinases-induced signal transduction for augmenting the thermotolerance of developing wheat (Triticum aestivum) grain under the heat stress. Journal of Plant Biochemistry and Biotechnology. 8(5), 697-705. DOI: 10.1007/s13562-014-0295-1.

18. Hagin, J., \& Tucker, B. (1982). Special Fertilization Practices and Multinutrient Fertilizers. In B. Yaron, D.F.R., Bommer, B.R., Sabey, G.W., Thomas, Y., Vaadia, L.D., Van Vleck (Eds.), Fertilization of Dryland and Irrigated Soils (pp. 141-165). Berlin Heidelberg New York: Springer-Verlag. DOI: 10.1007/978-3642-68327-5.

19. Hasanuzzaman, M., Bhuyan, M.H.M.B., Nahar, K., Hossain, M.D., Mahmud, J.A., Hossen, M.S., Masud, A.A.C., Moumita, Fujita, M. (2018). Potassium: A Vital Regulator of Plant Responses and Tolerance to Abiotic Stresses. Agronomy. 8(31), 1-29. DOI: 10.3390/agronomy8030031.

20. Hänsch, R., \& Mendel, R.R. (2009). Physiological functions of mineral micronutrients (Cu, $\mathrm{Zn}, \mathrm{Mn}, \mathrm{Fe}$, $\mathrm{Ni}, \mathrm{Mo}, \mathrm{B}, \mathrm{Cl})$. Current Opinion of Plant Biology. 12, 259-266.

21. Hotz, C., \& Braun, K.H. (2004). Assessment of the risk of zinc deficiency in populations and options for its control. Food and Nutrition Bulletin. 2, 194-204.

22. Imran, M., \& Gurmani, Z.A. (2011). Role of macro and micro nutrients in the plant growth and development. National Agricultural Research Centre. Retrieved March 3, 2018, from: http://agris.fao.org/agris-search/ search.do?recordID=PK2012000898. 
23. Jarecki, W., Buczek, J., \& Bobrecka-Jamro, D. (2017). Response of spring wheat to different soil and foliar fertilization. Journal of Central European Agriculture. 18(2), 460-476. DOI: 10.5513/JCEA01/18.2.1919.

24. Kaiser, H. (2014). Stomatal uptake of mineral particles from a sprayed suspension containing an organosilicone surfactant. Journal of Plant Nutrition and Soil Science. 177, 869-874.

25. Leszczyńska, D., Noworolnik, K., Grabiński, J., \& Jaśkiewicz, B. (2007). Ilość wysiewu nasion jako czynnik kształtujący plon ziarna zbóż (Seed sowing rate as a factor determining the grain yield of cereals). (In) Wybrane elementy technologii produkcji roślinnej (Chosen elements of plant production technology), A. Harasim ed., Studia i Raporty IUNG-PIB. 9, 17-27. (in Polish).

26. Nadim, M.A., Awan, I.U., Baloch, M.S., Khan, N., \& Naveed, K. (2013). Micronutrient use efficiency in wheat as affected by different application methods. Pakistan Journal of Botany. 45 (3), 887-892.

27. Nasiri, Y., Zehtab-Salmasi, S., Nasrullahzadeh, S., Najafi, N., \& Ghassemi-Golezani, K. (2010). Effects of foliar application of micronutrients ( $\mathrm{Fe}$ and $\mathrm{Zn}$ ) on flower yield and essential oil of chamomile (Matricaria chamomilla L.). Journal of Medicinal Plants Research. 4(17), 1733-1737.

28. Oscarson, P. (2000). The strategy of the wheat plant in acclimating growth and grain production to nitrogen availability. Journal of Experimental Botany. 51, (352), 1921-1929.

29. Plaxton, W.C., \& Tran, H.T. (2011). Metabolic Adaptations of Phosphate-Starved Plants. Plant Physiology. 156(3), 1006-1015. DOI: 10.1104/pp.111.175281.

30. Raun, W.R., \& Johnson, G.V. (1999). Improving nitrogen use efficiency for cereal production. Agronomy Journal. 91, 357-362.

31. Rawashdeh, H., \& Sala, F. (2015). Effect of some micronutrients on growth and yield of wheat and its leaves and grain content of iron and boron. Bulletin USAMV series Agriculture. 72(2), 503-508. DOI: 10.15835/buasvmen-agr: 11334.

32. Rawashdeh, H.M., \& Sala, F. (2016) The effect of iron and boron foliar fertilization on yield and yield components of wheat. Romanian Agriculture Research. 33, 1-9.

33. Raza, S.A., Ali, S., Chahill, Z.S., \& Iqbal, R.M. (2014). Response of foliar application of boron on wheat (Triticum aestivum L) crop in calcareous soils of Pakistan. Academia Journal of Agricultural Research. 2(3), 106-109.

34. Ronen, E. (2007). Micro-elements in agriculture. Practical Hydroponics and Greenhouses. July/August, 39-48.

35. Seadh, S.E., EL-Abady, M.I., El-Ghamry, A.M., \& Farouk, S. (2009). Influence of micronutrients foliar application and nitrogen fertilization on wheat yield and quality of grain and seed. Journal of Biological Sciences. 9 (8), 851-858.

36. Stępień, A., \& Wojtkowiak, K. (2016). Effect of foliar application of $\mathrm{Cu}, \mathrm{Zn}$, and $\mathrm{Mn}$ on yield and quality indicators of winter wheat grain. Chilean Journal of Agricultural Research. 76(2), 220-227. DOI: 10.4067/ S0718-5839016000200012.

37. Tahir, M., Tanveer, A., Shah, T.H., Fiaz, N., \& Wasaya, A. (2009). Yield response of wheat (Triticum aestivum L.) to boron application at different growth stages. Pakistan Journal of Social Sciences. 7 (1), 39-42.

38. Thakur, N., Sharma, V., \& Kishore, K. (2016). Leaf senescence: an overview. Indian Journal of Plant Physiology. 21(3), 225-238. DOI: 10.1007/s40502-016-0234-3.

39. Tripolskaja, L., Ražukas, A., Šidlauskas, G., \& Verbylienè, I. (2017). Effect of fertilizers with different chemical composition on crop yield, nitrogen uptake and leaching in sandy loam Luvisol. ZemdirbysteAgriculture. 104(3), 203-208. DOI: 10.13080/z-a.2017.104.026.

40. Welch, R.M., Allaway, W.H., House, W.A., \& Kubota, J. (1991). Geographic distribution of trace element problems. In J.J. Mortvedt, F.R., Cox, L.M., Shuman \& R.M. Welch (Eds.), Micronutrients in agriculture (pp. 31-57). Madison, Wisconsin, USA: Soil Science Society of America, Inc.

41. Zain, M., Qadri, R.W.K., Ashraf, U., Hussain, S., Siddique, A., Jahangir, M.M., \& Bashir, M. (2015). Foliar application of micronutrients enhances wheat growth, yield and related attributes. American Journal of Plant Sciences. 6, 864-869.

42. Ziaeian, A.H., \& Malakouti, M.J. (2001). Effects of Fe, Mn, Zn and Cu fertilization on the yield and grain quality of wheat in the calcareous soils of Iran. In W.J. Horst, M.K. Schenk, A. Bürkert, N. Claassen, H. Flessa, W.B. Frommer, Heiner E. Goldbach, H.-W. Olfs, V. Römheld, B. Sattelmacher, U. Schmidhalter, S. Schubert, N. von Wirén, L. Wittenmayer (Eds.), Plant Nutrition: Food security and sustainability of agroecosystems through basic and applied research (pp. 840-841). Dordrecht: Kluwer Academic Publishers. 